\title{
Multi-instrument observations of nightside plasma patches under conditions of IMF $B_{z}$ positive
}

\author{
A. G. Wood ${ }^{1}$, S. E. Pryse ${ }^{1}$, H. R. Middleton ${ }^{1}$, and V. S. C. Howells ${ }^{2}$ \\ ${ }^{1}$ Aberystwyth University, Aberystwyth, UK \\ ${ }^{2}$ Rutherford Appleton Laboratory, Didcot, UK
}

Received: 30 November 2007 - Revised: 7 March 2008 - Accepted: 5 April 2008 - Published: 5 August 2008

\begin{abstract}
Results are presented from two multi-instrument case studies showing patches of cold, long-lived plasma in the winter nightside ionosphere during times when the $\mathrm{z}$ component of the Interplanetary Magnetic Field (IMF $B_{z}$ ) was positive. These enhancements were coincident with the antisunward convective plasma drift, flowing from polar to nightside auroral latitudes. In the first case, on 5 December 2005 with IMF $B_{y}$ negative, two regions of enhanced electron density were observed extended in MLT in the magnetic midnight sector separated by lower densities near midnight. It is likely that the earlier enhancement originated on the dayside near magnetic noon and was transported to the nightside sector in the convective flow, whilst the later feature originated in the morning magnetic sector. The lower densities separating the two enhancements were a consequence of a pair of lobe cells essentially blocking the direct antisunward cross polar flow from the dayside. A second case study on 4 February 2006 with IMF $B_{y}$ positive revealed a single nightside enhancement likely to have originated in the morning magnetic sector. These multi-instrument investigations, incorporating observations by the EISCAT radar facility, the SuperDARN network and radio tomography, reveal that plasma flowing from the dayside can play a significant role in the nightside ionosphere under conditions of IMF $B_{z}$ positive. The observations are reinforced by simulations of flux-tube transport and plasma decay.
\end{abstract}

Keywords. Ionosphere (Plasma convection; Plasma temperature and density; Polar ionosphere)

Correspondence to: A. G. Wood

(aow@aber.ac.uk)

\section{Introduction}

Ionospheric plasma in the polar cap is structured on a wide range of horizontal spatial scale sizes (e.g. Tsunoda, 1988). Structuring on large scales results in F-region electron density enhancements known as polar cap patches. These have a horizontal extent of at least $100 \mathrm{~km}$ and plasma densities of at least twice the surrounding background density (Crowley, 1996). Buchau et al. (1983) observed patches at Thule, Greenland $\left(77.50^{\circ} \mathrm{N}, 69.20^{\circ} \mathrm{W} ; 85.43^{\circ}\right.$ MLAT, $32.38^{\circ}$ MLON) drifting antisunward with the background plasma flow. The flux of precipitating particles in the central region of the polar cap was insufficient to produce the patch densities and therefore it was concluded that the patches were not produced locally by in situ precipitation. Weber et al. (1984) proposed that the patches were produced on the dayside at auroral or subauroral latitudes and then convected antisunward to higher, polar latitudes. In winter, patches have been observed to travel across the entire polar cap (Weber et al., 1986) and an individual patch was followed for over $3000 \mathrm{~km}$ from the centre of the polar cap to the poleward edge of the nightside auroral oval. Measurements of the patch density and the surrounding background density showed that both decreased by a factor of two during the transit of the patch, in good agreement with F-region recombination rates. Recombination is greater at lower altitudes (e.g. Brekke, 1997) and so patch-lifetime depends on altitude, with patches at greater altitudes having longer lifetimes (e.g. Walker et al., 1999).

Polar cap patches drift in the high latitude convection, the patterns for which are illustrated under different Interplanetary Magnetic Field (IMF) conditions in Reiff and Burch (1985) and Heelis (1988). Under conditions of IMF $B_{z}$ negative the convection pattern is driven by magnetic reconnection between the IMF and the geomagnetic field near the equatorial plane and antisunward flow occurs across the polar cap. Variation in IMF $B_{y}$ results in a displacement of the

Published by Copernicus Publications on behalf of the European Geosciences Union. 
convection pattern towards dawn (dusk) for positive (negative) values. The relative importance of IMF $B_{z}$ and IMF $B_{y}$ is given by the clock angle, $\theta$.

$\theta=\arctan \frac{\left|B_{y}\right|}{B_{z}}$

For clock angles of less than $70^{\circ}$ the convection pattern is driven by reconnection in the magnetospheric lobe (Freeman et al., 1993) and the resulting lobe convection cells occur with sunward plasma flow near local noon (Lockwood and Moen, 1999). Polar cap patches are generally associated with IMF $B_{z}$ negative (Valladares et al., 1988), although they have also been observed at times of IMF $B_{z}$ positive. Using an ionosonde and optical instruments McEwen and Harris (1996) observed 523 patches close to the geomagnetic pole $\left(89^{\circ}\right.$ MLAT) during four winters and found that they were primarily associated with times of IMF $B_{z}$ negative, although $20 \%$ occurred during times of IMF $B_{z}$ positive. Closer inspection of the latter group showed that, in most cases, either IMF $B_{z}$ was close to zero or had become positive within two hours previous to observations and it was proposed that the patches under IMF $B_{z}$ positive had entered the polar cap under IMF $B_{z}$ negative (McEwen and Harris, 1996). Middleton et al. (2005) observed a tongue-of-ionisation under conditions of IMF $B_{z}$ positive being swept around the periphery of the polar cap in the post-noon sector.

Patch occurrence exhibits an UT dependence. Observations by Buchau et al. (1985) at Thule, Greenland showed patches present between 13:00 UT and 00:00 UT with maximum electron density around 18:00 UT, although this could be as late as 21:00 UT. Comparison of patch densities with electron densities two degrees equatorward of the cusp suggested photoionisation as a plasma source for the patches. Later modelling studies by Sojka et al. (1994) in the magnetic midnight sector at $80^{\circ}$ MLAT showed that, at winter solstice, patches were most intense between 20:00 UT and 00:00 UT and absent between 08:00 UT and 12:00 UT. The UT dependence here also suggested photoionisation as a source of patch plasma with the variation arising because of the offset between the geographic and geomagnetic poles (Coley and Heelis, 1998). The high latitude convection pattern is driven in the geomagnetic reference frame, which is approximately centred on the geomagnetic pole. At around 18:00 UT, when the geomagnetic pole is sunward of the geographic pole, the convection pattern therefore reaches lower geographic latitudes at local noon than at other universal times. Photoionisation is a function of geographic latitude and so when the high latitude convection pattern reaches lower geographic latitudes larger plasma densities are entrained into the polar cap flow. This suggests that the European sector should be favourable for observing nightside patch enhancements.

While patches have been studied extensively in the dayside ionosphere and in the central regions of the polar cap, studies in the night sector are less common. Nightside patches have been observed by Weber et al. (1986), however in this study the IMF conditions were not known. Patches have been predicted from modelling under conditions of IMF $B_{z}$ negative using the Utah State University Time Dependant Ionospheric Model (TDIM) for different orientations of IMF $B_{y}$ (Bowline et al., 1996). Variations in $B_{y}$ modified the symmetry of the convection pattern and, although this did not alter the prediction of patches in the nightside ionosphere, it did alter the location at which they were expected. Using eight years of meridian scanning photometer data on the nightside, Moen et al. (2007) identified airglow from 333 F-region polar cap patches that merged into the poleward boundary of nighttime aurorae under conditions of IMF $B_{z}$ negative. The MLT distribution of the patches was symmetric around 23:25 MLT and, using the statistical flow patterns of Ruohoniemi and Greenwald (2005), this indicated that patches did not preferentially originate from either the dawn or dusk cell. It was thus concluded that there was no IMF $B_{y}$ dependence in the statistical occurrence of nightside polar cap patches. Patches on the nightside in winter have also been observed by the Sondrestrom Incoherent Scatter radar drifting out of the polar cap and into the auroral zone (Pedersen et al., 2000). Lorentzen et al. (2004) observed airglow from patches on the nightside exiting the polar cap by crossing the open closed field line boundary (OCB) during tail reconnection under IMF $B_{z}$ negative and predominantly $B_{y}$ positive. Pryse et al. (2006) observed a patch in the nightside polar ionosphere which reconfigured to form a boundary blob at the equatorward edge of the evening auroral sector.

To date, polar cap patches have not been reported in the nightside ionosphere under conditions of IMF $B_{z}$ positive. In this current paper two multi-instrument studies from 5 December 2005 and 4 February 2006 are presented showing the presence of polar patches when IMF $B_{z}$ was positive and stable. The regions of enhanced electron density are identified and their origin is discussed.

\section{Instrumentation}

\subsection{EISCAT Svalbard radar}

The European Incoherent SCATter radar facility (EISCAT) comprises several radars on mainland Scandinavia and at Longyearbyen on Svalbard. Of particular interest to this study are measurements of electron density and temperature, and line-of-sight plasma drift velocity made by the EISCAT Svalbard Radar (ESR) located at $78.2^{\circ} \mathrm{N}, 16.0^{\circ} \mathrm{E} ; 75.2^{\circ}$ MLAT, $112.9^{\circ}$ MLON, using the TOI/NIGHT UK special programme. The $42 \mathrm{~m}$ dish of the radar observed along the geomagnetic field in the F-region (azimuth $-179.0^{\circ}$; elevation $81.6^{\circ}$ ) with the beam at $77.8^{\circ} \mathrm{N}, 16.0^{\circ} \mathrm{E} ; 74.9^{\circ}$ MLAT, $111.5^{\circ}$ MLON at an altitude of $300 \mathrm{~km}$. The $42 \mathrm{~m}$ dish was used to monitor the temporal evolution of plasma. The $32 \mathrm{~m}$ dish of the radar was used to infer the spatial latitudinal distribution of the plasma by scanning in the geographic 


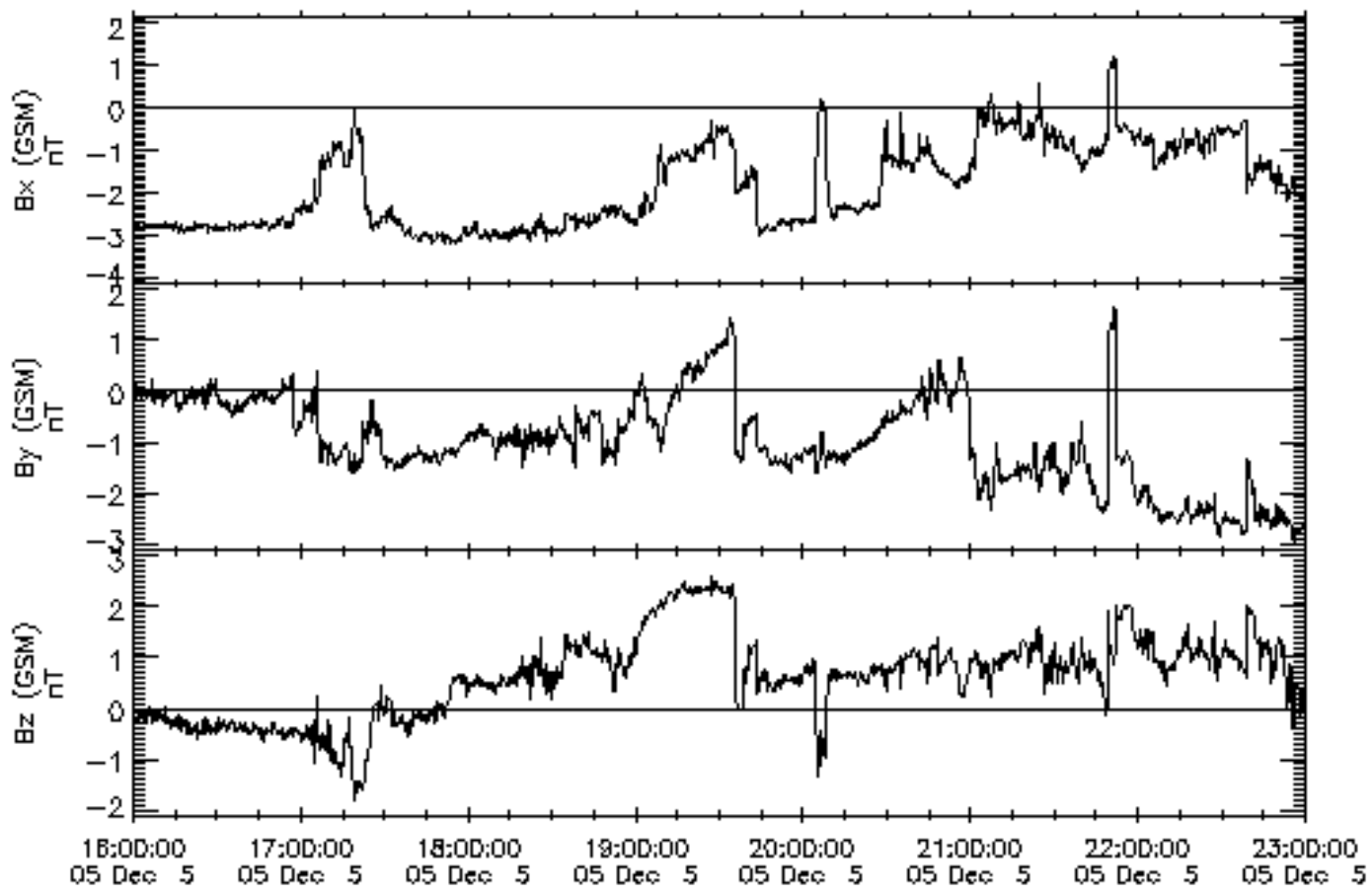

Fig. 1. The $\mathrm{x}-$, $\mathrm{y}$ - and z-components of the interplanetary magnetic field observed by the ACE spacecraft between 16:00 UT and 23:00 UT on 5 December 2005.

meridian. Each scan commenced at an elevation of $35.1^{\circ}$ to the north and finished at an elevation of $35.1^{\circ}$ to the south. The scan contained 36 positions with a dwell time of $32 \mathrm{~s}$ at each pointing direction, and had a total cycle time of approximately $20 \mathrm{~min}$.

\subsection{SuperDARN radar network}

The Super Dual Auroral Radar Network (SuperDARN) is a network of high latitude coherent scatter radars comprising nine radars in the Northern Hemisphere and seven in the Southern Hemisphere (Greenwald et al., 1995) which observe line-of-sight plasma velocities in the F-region. These measurements can be inverted using the spherical harmonic fitting technique of Ruohoniemi and Baker (1998) to infer the high-latitude electric potential patterns in the Northern and Southern Hemispheres. As the plasma drift velocity is perpendicular to both the electric and magnetic fields in the F-region $(\boldsymbol{E} \times \boldsymbol{B}$ drift) the plasma convection pattern can be directly inferred from the electric potential maps.

\subsection{Radio tomography}

The ionospheric radio tomography experiment of Aberystwyth University comprises a chain of receiving stations in Northern Scandinavia, with the receivers separated in latitude but essentially aligned in longitude at Troms $\varnothing$ $\left(69.8^{\circ} \mathrm{N}, 19.0^{\circ} \mathrm{E} ; 66.1^{\circ}\right.$ MLAT, $103.4^{\circ}$ MLON), Bjørnoya $\left(74.5^{\circ} \mathrm{N}, 19.0^{\circ} \mathrm{E} ; 71.3^{\circ} \mathrm{MLAT}, 108.8^{\circ} \mathrm{MLON}\right)$, Longyear- byen $\left(78.2^{\circ} \mathrm{N}, 15.7^{\circ} \mathrm{E} ; 75.1^{\circ}\right.$ MLAT, $113.0^{\circ}$ MLON) and $\mathrm{Ny}$-Ålesund $\left(78.9^{\circ} \mathrm{N}, 12.0^{\circ} \mathrm{E} ; 76.0^{\circ} \mathrm{MLAT}, 112.3^{\circ}\right.$ MLON). These stations monitor coherent radio signals at $150 \mathrm{MHz}$ and $400 \mathrm{MHz}$ from polar orbiting satellites for measurement of total electron content along a large number of intersecting satellite-to-receiver ray paths. The electron content observations are inverted in a tomographic reconstruction algorithm to yield the spatial distribution of electron density over a latitude-versus-altitude plane (Pryse, 2003, and references therein).

\subsection{Defense Meteorological Satellite Program}

The Defense Meteorological Satellite Program (DMSP) observes the Earth and space environment with satellites in near-polar orbits at altitudes of $835 \mathrm{~km}$ to $850 \mathrm{~km}$ and a period of some $100 \mathrm{~min}$. Of particular relevance to the current study are the measurements of the energy flux of precipitating electrons made by the SSJ/4 particle detectors on satellites F13, F15 and F16 (Hardy et al., 1984).

\section{Results: 5 December 2005}

\subsection{Geophysical conditions}

The Advanced Composition Explorer (ACE) spacecraft monitors the solar wind at the Lagrangian point L1, approximately $1.5 \times 10^{6} \mathrm{~km}$ upstream from the Earth on the 

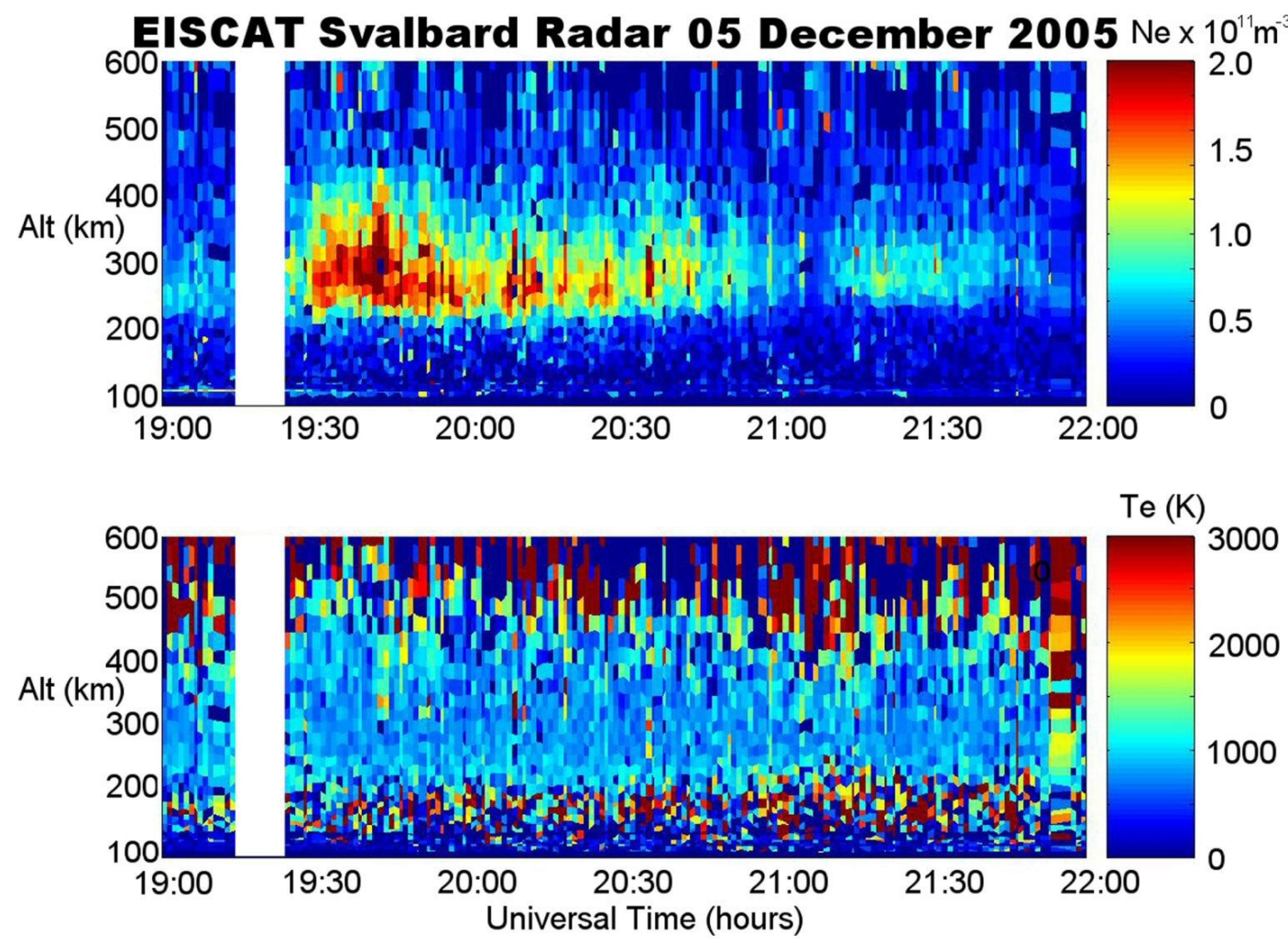

Fig. 2. Electron densities (top panel) and electron temperatures (bottom panel) measured by the $42 \mathrm{~m}$ dish of the EISCAT Svalbard Radar observing along the geomagnetic field between 19:00 UT and 22:00 UT on 5 December 2005.

Sun-Earth line (Zwickl et al., 1998). The x-, y- and zcomponents of the Interplanetary Magnetic Field (IMF) in geomagnetic co-ordinates observed between 16:00 UT and 23:00 UT on 5 December 2005 are shown in the three panels of Fig. 1. Between 16:00 UT and 17:00 UT IMF $B_{z}$ was weakly negative with a mean value of $-0.3 \mathrm{nT}$, IMF $B_{y}$ was weakly negative with a mean value of $-0.1 \mathrm{nT}$ and the clock angle was approximately $110^{\circ}$. There was then a brief excursion of IMF $B_{z}$ to $-1.6 \mathrm{nT}$ at 17:20 UT. IMF $B_{z}$ was stable and positive between 17:50 UT and 23:00 UT with a mean value of $1.0 \mathrm{nT}$, IMF $B_{y}$ was mainly negative with a mean value of $-1.2 \mathrm{nT}$ and the clock angle was approximately $50^{\circ}$. The solar wind velocity at the time was approximately $350 \mathrm{~km} \mathrm{~s}^{-1}$ and the delay between the observations at the L1 point and the response of the ionosphere was about $82 \mathrm{~min}$ using the method of Lockwood et al. (1989). The $\mathrm{F}_{10.7}$ solar flux index was $91.7 \mathrm{sfu}$ and $K_{p}$ was stable, taking values of 1- and 0 between 18:00 UT and 24:00 UT.

\subsection{Electron densities and temperatures}

The electron densities and temperatures observed by the field-aligned $42 \mathrm{~m}$ dish of the EISCAT Svalbard Radar (ESR) between 19:00 UT and 22:00 UT are shown in Fig. 2. A clear region of enhanced electron densities was observed between 19:24 UT and 20:59 UT above the $0.7 \times 10^{11} \mathrm{~m}^{-3}$ level at the peak altitude of $275 \mathrm{~km}$. The average density of the enhancement at this altitude was $1.4 \times 10^{11} \mathrm{~m}^{-3}$. A background electron density value of $0.3 \times 10^{11} \mathrm{~m}^{-3}$ was established for the observations, taken as the mean of the lowest $25 \%$ of electron density observations at $275 \mathrm{~km}$ during the entire experiment (18:00 UT to 24:00 UT) which included the data presented in Fig. 2. The precise timing of the onset of the enhancement could not be determined due to the data gap between 19:15 UT and 19:24 UT but this was not of significance for the study under discussion. The largest densities were observed in the earlier part of the feature with a maximum density of $2.7 \times 10^{11} \mathrm{~m}^{-3}$ at 19:42 UT. Lower densities were observed at later times, with the electron densities reducing to $0.7 \times 10^{11} \mathrm{~m}^{-3}$ at $20: 59 \mathrm{UT}$. A second region of enhanced electron densities was later observed between 21:11 UT and 21:32 UT with an average electron density of $0.8 \times 10^{11} \mathrm{~m}^{-3}$ at $275 \mathrm{~km}$. The two enhancements were separated by a region of lower densities of $0.5 \times 10^{11} \mathrm{~m}^{-3}$. Electron temperatures, shown in the lower panel of Fig. 2, took values of about $850 \mathrm{~K}$ between 19:00 UT and 22:00 UT in both the enhanced and background densities, and ruled out the production of the enhancements by local precipitation.

Electron densities observed by the $32 \mathrm{~m}$ dish of the ESR between 19:26 UT and 20:46 UT are shown in Fig. 3. A region of enhanced electron densities with a peak value of 
$2.2 \times 10^{11} \mathrm{~m}^{-3}$ was observed equatorward of $79^{\circ} \mathrm{N}$ in the first scan starting at 19:26 UT. The beam of the $42 \mathrm{~m}$ dish intersected this scan at $78^{\circ} \mathrm{N}$ and observed similar density levels of $1.6 \times 10^{11} \mathrm{~m}^{-3}$ at 19:34 UT. Poleward of $79^{\circ} \mathrm{N}$ the $32 \mathrm{~m}$ dish observed lower electron densities, taking an average value of $0.5 \times 10^{11} \mathrm{~m}^{-3}$. In each of the following three scans progressively lower electron densities were observed in the enhancement. Evidence for a second density enhancement is seen in the second panel, poleward of $80^{\circ} \mathrm{N}$. Corresponding electron temperatures (not shown) took values of about $820 \mathrm{~K}$ across the entire field of view of the scans and ruled out the production of the enhancement by local precipitation.

The radio tomography experiment observed the spatial distribution of electron density on a wider latitudinal spatial scale. Electron densities observed by the experiment during satellite passes that crossed a latitude of $75^{\circ} \mathrm{N}$ at 19:11 UT and 21:51 UT are shown respectively in the top two panels of Fig. 4. Each satellite pass has a duration of some $15 \mathrm{~min}$. The $350 \mathrm{~km}$ intersection through the images are shown on the magnetic co-ordinate system (MLAT-versus-MLT) in the lower panels of Fig. 4 with the colours indicating the electron density at the F-region peak. Also shown in these panels are the coincident electric potential patterns inferred by the SuperDARN radars, which are discussed in more detail in Sect. 3.3.

The radio tomography image at 19:11 UT showed three regions of enhanced electron density in the evening sector centred on $71.6^{\circ} \mathrm{N}, 76.0^{\circ} \mathrm{N}$ and $81.0^{\circ} \mathrm{N}$ with corresponding electron densities of $1.4 \times 10^{11} \mathrm{~m}^{-3}, 1.7 \times 10^{11} \mathrm{~m}^{-3}$ and $1.2 \times 10^{11} \mathrm{~m}^{-3}$, respectively. Their peak altitude was about $390 \mathrm{~km}$, higher than observed by the ESR. Caution should be exercised in inferring the altitude from the tomography images because of geometrical constraints leading to limitations in the technique to determine the vertical distribution of the electron density (Pryse, 2003). However, this restricted ability to determine the altitude of the peak electron density does not detract from the validity of the method to locate the latitudinal locations of the enhancements. By comparison with the corresponding SuperDARN convection pattern, the enhancements centred at $76.0^{\circ} \mathrm{N}$ and $81.0^{\circ} \mathrm{N}$ were in antisunward cross polar flow, whilst that centred on $71.6^{\circ} \mathrm{N}$ was in return sunward flow slightly equatorward of the convection reversal. At 19:11 UT the ESR $42 \mathrm{~m}$ radar observed a peak electron density of $0.4 \times 10^{11} \mathrm{~m}^{-3}$ at $275 \mathrm{~km}$ (Fig. 2), which preceded the large enhancement it observed a few minutes later. This apparent discrepancy between the time of enhancement observed by radio tomography and the ESR radar can be explained by geometrical effects. The trajectory of the $350 \mathrm{~km}$ intersection of the satellite trajectory was poleward of the radar, which is indicated by the red cross on the convection map. It is therefore not unreasonable to conclude that the enhancement was observed in the tomography field of view before it was seen by the ESR downstream in the convection pattern.
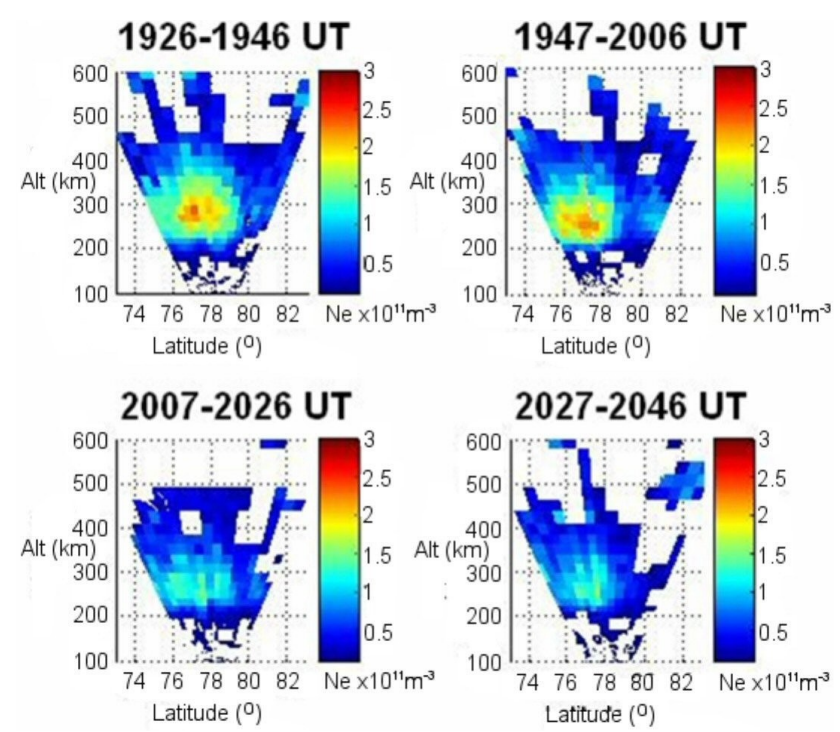

Fig. 3. Electron densities measured by the $32 \mathrm{~m}$ dish of the EISCAT Svalbard Radar scanning from north to south along the geographic meridian between 19:26 UT and 20:46 UT on 5 December 2005.

The second radio tomography image at 21:51 UT intersected the magnetic post-midnight sector. The peak electron density values were much lower than in the earlier pass, typically $0.8 \times 10^{11} \mathrm{~m}^{-3}$ between $69.0^{\circ} \mathrm{N}$ and $77.0^{\circ} \mathrm{N}$. Between $78.0^{\circ} \mathrm{N}$ and $84.0^{\circ} \mathrm{N}$ the peak electron density did not exceed $0.2 \times 10^{11} \mathrm{~m}^{-3}$. Comparison with the SuperDARN convection pattern showed that the trajectory of this satellite pass did not intersect the antisunward flow of the dusk convection cell. The trajectory may have intersected the dawn convection cell, although caution is needed in this interpretation due to the absence of radar measurements in this region. Electron densities observed in this sector by the ESR $42 \mathrm{~m}$ dish at $78^{\circ} \mathrm{N}$, almost colocated with the tomography observations, were $0.5 \times 10^{11} \mathrm{~m}^{-3}$ in broad agreement with the tomography values.

\subsection{High latitude electric potential pattern.}

High latitude convection patterns were inferred from the SuperDARN electric potential maps at 2-min intervals. Representative plots at roughly 30-min intervals are shown in Fig. 5, with the panels being for 19:06 UT, 19:28 UT, 19:56 UT, 20:24 UT, 21:00 UT and 21:26 UT, rather than at strictly 30-min separations, to ensure reasonable coverage by backscatter measurements. The convection patterns were reasonably stable between 19:00 UT and 22:00 UT and dominated by a dusk convection cell. The dusk cell was likely to be drawing plasma antisunward from near magnetic noon and a smaller dawn cell may have been drawing plasma antisunward from the morning sector. The red cross on each plot indicates the position of the intersection of the ESR beam at an altitude of $300 \mathrm{~km}$, and shows that the radar was observing 

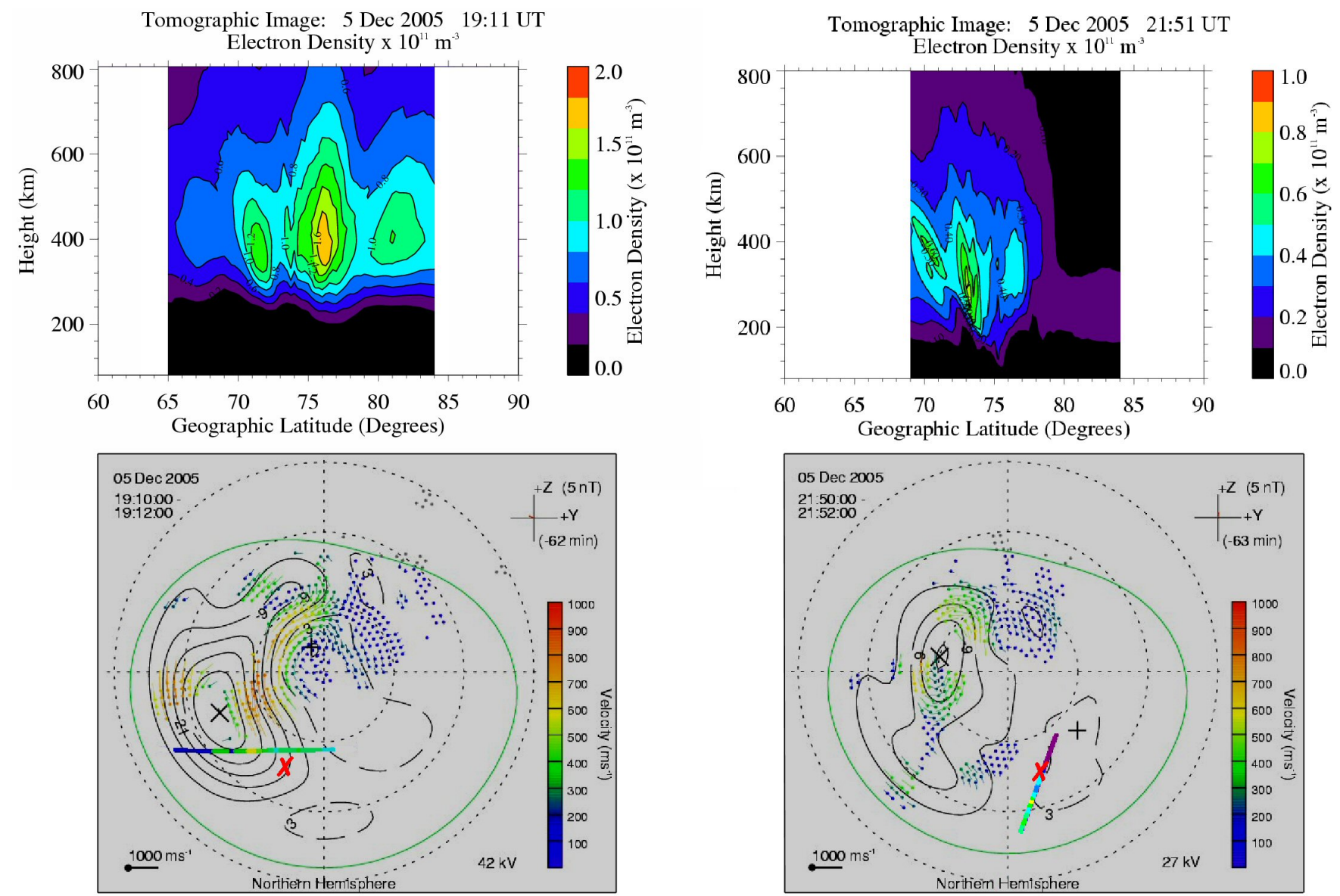

Fig. 4. Electron densities observed by the radio tomography experiment during a satellite pass that crossed a latitude of $75^{\circ} \mathrm{N}$ at $19: 11 \mathrm{UT}$ (top left panel) and 21:51 UT (top right panel), and the corresponding electric potential patterns inferred from the SuperDARN radars at 19:11 UT (bottom left panel) and 21:51 UT (bottom right panel). The multicoloured lines on the potential maps indicate the satellite trajectories intersecting the ionosphere at an altitude of $350 \mathrm{~km}$ with the colours representing the electron density at the F-region peak of the tomography image. To clearly show the electron density observed by the radio tomography experiment at 21:51 UT an electron density scale is used in the right hand panels with a maximum value of half that used in the left hand panels. The red crosses represent the position of the EISCAT Svalbard Radar.

in the antisunward flow throughout the interval of interest. The larger density enhancement observed by ESR prior to 21:00 UT clearly corresponded to the dusk cell whilst the smaller enhancement at later times was likely to have been in the dawn cell. Figure 6 shows the SuperDARN electric potential pattern for 20:10 UT. The time of 20:10 UT was chosen as it is close to the centre of the time range of the ESR $32 \mathrm{~m}$ dish scans plotted in Fig. 3. The latitudinal coverage of the four successive scans of the ESR $32 \mathrm{~m}$ dish at an altitude of $300 \mathrm{~km}$ are also plotted as red lines. Of particular note is the fact that the higher geographic latitudes of the scans correspond to later magnetic local times and it is likely that the northern field-of-view of the radar scans was in the dawn convection cell, whilst the equatorward portion was in the antisunward flow of the dusk cell. This interpretation is consistent with the electron densities in Fig. 3, where the enhancement in the southern field of view is associated with the dusk cell, whilst the lower densities and smaller enhancement in panel 2 of Fig. 3 are likely to be within the dawnside cell. The blue curves schematically emphasise the convection pattern, including a pair of lobe cells close to $85^{\circ}$ MLAT, 12:00 MLT. Lobe cells were also observed in this vicinity on each of the plots in Fig. 5, however they are more difficult to identify due to the contouring.

\subsection{Precipitation}

The DMSP F13, F15 and F16 satellites observed the energy flux of ions and electrons at high latitudes in the Northern Hemisphere. An energy flux of electrons in excess of $1 \times 10^{7} \mathrm{~cm}^{-2}$ ster $^{-1} \mathrm{~s}^{-1}$ at an energy of $250 \mathrm{eV}$ was taken as signature of electron precipitation into the ionosphere. Between 17:00 UT and 22:00 UT a total of 10 such satellite passes occurred and the trajectories of these satellites are 

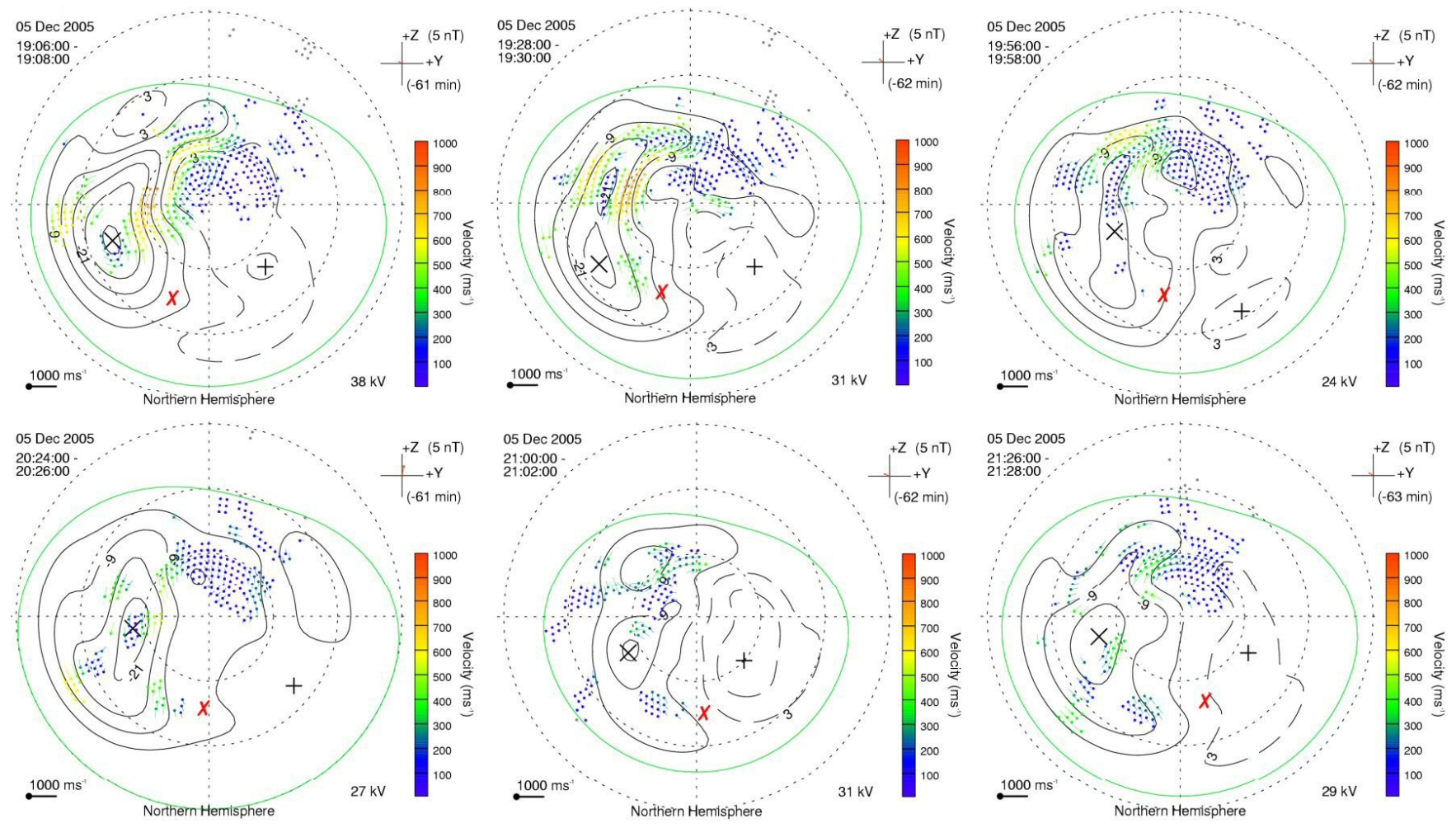

Fig. 5. Electric potential patterns inferred from the SuperDARN radars for 19:06 UT, 19:28 UT, 19:56 UT, 20:24 UT, $21: 00$ UT and 21:26 UT on 5 December 2005. The red crosses indicate the position of the EISCAT Svalbard Radar beam at an altitude of $300 \mathrm{~km}$.

plotted in Fig. 7. The parts coloured red indicate where the flux threshold is exceeded. The blue curves show the schematic representation of the high latitude convection pattern, reproduced from Fig. 6. Comparison of the plasma flow with the regimes of precipitation on the satellite trajectories showed that the antisunward plasma flow of the dusk cell did not pass through a region of ongoing precipitation, and this was ruled out as a mechanism for maintaining densities as the plasma flowed from the dayside to the premidnight sector. At earlier MLTs, in the afternoon sector, there were no DMSP observations to establish the occurrence of precipitation, however a contribution by precipitation to the ionisation production in this region would have been small compared to photoionisation (e.g. Walker et al., 1999). The plasma flowing antisunward in the dawn cell did pass through a region of precipitation, and so in this instance precipitation may have contributed to the densities observed in the postmidnight sector.

\section{Results: 4 February 2006}

\subsection{Geophysical conditions}

The three components of the IMF observed by the ACE spacecraft between 16:00 UT and 23:00 UT on 4 February
2006 are shown in Fig. 8. During this interval IMF $B_{z}$ was initially strongly positive with an average value of $2.6 \mathrm{nT}$ between 16:00 UT and 21:30 UT, after which it reduced in magnitude. At 21:54 UT IMF $B_{z}$ turned negative and remained negative until after 23:00 UT. IMF $B_{y}$ was stable and strongly positive throughout the evening with an average value of $4.6 \mathrm{nT}$ between 16:00 UT and 23:00 UT. The clock angle was approximately $60^{\circ}$ between 16:00 UT and 21:30 UT, after which it increased and was approximately $110^{\circ}$ between 22:00 UT and 23:00 UT. The solar wind velocity was about $365 \mathrm{~km} \mathrm{~s}^{-1}$ giving a delay in the ionospheric response of approximately 70 min using the method of Lockwood et al. (1989). The $\mathrm{F}_{10.7}$ solar flux was 77.0 sfu and $K_{p}$ was stable, being 0+ between 18:00 UT and 24:00 UT.

\subsection{Electron densities and temperatures}

Electron densities and temperatures observed by the fieldaligned $42 \mathrm{~m}$ dish of the ESR between 19:00 UT and 22:00 UT are shown in Fig. 9. A region of enhanced electron densities was observed between 19:35 UT and 21:11 UT defined by the $0.5 \times 10^{11} \mathrm{~m}^{-3}$ contour with an average electron density of $0.9 \times 10^{11} \mathrm{~m}^{-3}$ and a peak altitude of $255 \mathrm{~km}$. All densities above $1.95 \times 10^{11} \mathrm{~m}^{-3}$ are shown by the top colour on the scale and the maximum electron density of $2.4 \times 10^{11} \mathrm{~m}^{-3}$ at $255 \mathrm{~km}$ occurred at $20: 29 \mathrm{UT}$. 


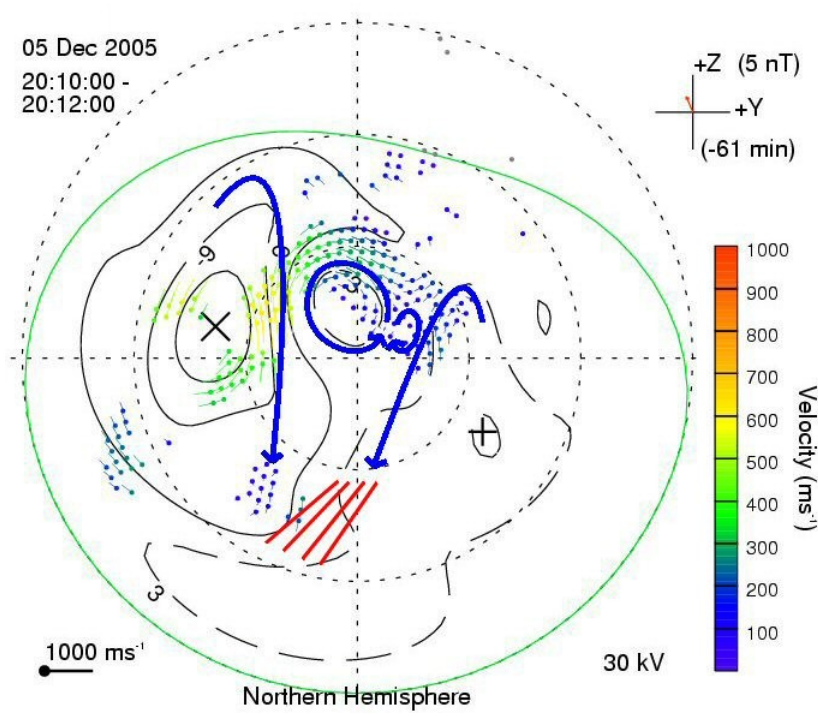

Fig. 6. Electric potential pattern inferred from the SuperDARN radars for 20:10 UT on 5 December 2005. The red lines indicate the positions of the $300 \mathrm{~km}$ ionospheric intersection of successive scans by the EISCAT Svalbard Radar commencing at 19:26 UT, 19:47 UT, 20:07 UT and 20:27 UT. The blue curves are a schematic of the high latitude convection pattern.

The background density for the 18:00 UT to 24:00 UT interval, which included the data presented in Fig. 9, was $0.3 \times 10^{11} \mathrm{~m}^{-3}$. Electron temperatures were about $900 \mathrm{~K}$ throughout the observations and therefore in situ precipitation was ruled out as a source of the enhanced densities.

\subsection{Plasma drift flow}

Representative high latitude electric potential maps obtained by the SuperDARN radars at 2-min resolution are shown in Fig. 10a for 19:10 UT, 19:40 UT, 20:10 UT and 20:40 UT. The convection pattern did not show significant variation between 19:00 UT and 22:00 UT. There is very little data in the midnight sector, however there is sufficient data on the dayside to show a two cell convection pattern with plasma drawn from the magnetic morning sector towards the midnight sector. On the dayside the convection pattern was dominated by two cells, with the dusk cell being significantly larger than the dawn cell. Support for the nightside flow is provided by the ESR $32 \mathrm{~m}$ dish that was scanning along the geographic meridian from north to south. Its $300 \mathrm{~km}$ altitude intersection is shown on the third panel of Fig. 10a for 20:10 UT, and the line-of-sight plasma drift velocities that it measured between 19:55 UT and 20:15 UT are shown in Fig. 10b. These radar observations are representative of those for the interval from 19:35 UT to 20:55 UT, and show a flow component towards the radar in the northern field of view and away from the radar in the southern field of view, consistent with it being located in the antisunward flow.

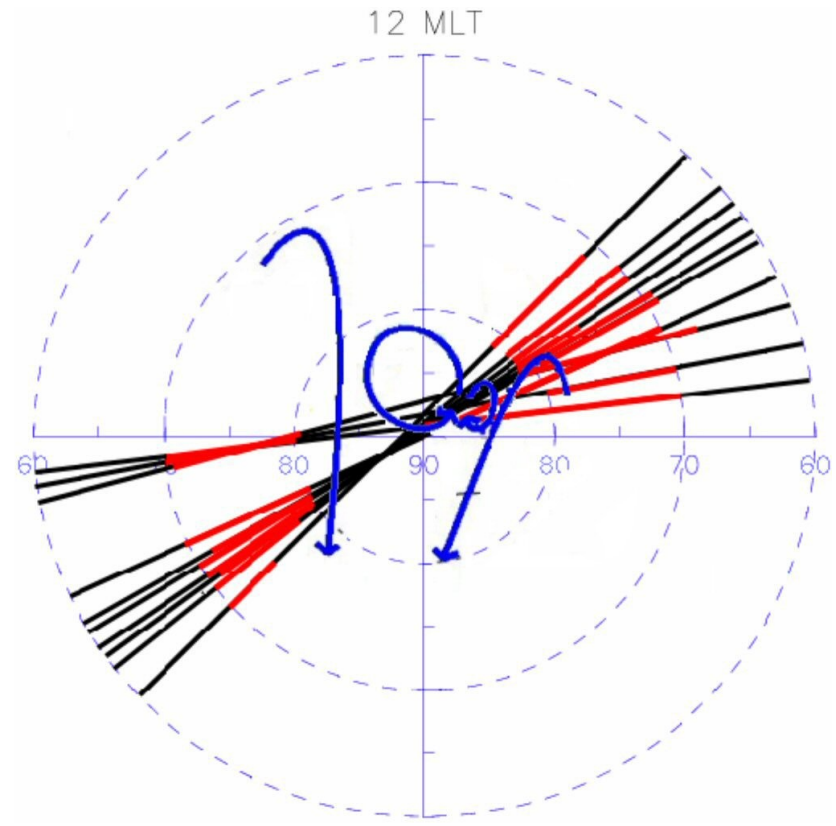

Fig. 7. The trajectories of F13, F15 and F16 DMSP satellite passes between 17:00 UT and 22:00 UT over northern high latitudes on 5 December 2005. The red portions of the trajectory lines, indicate regions where precipitation is occurring and the blue curves are a schematic of the high latitude convection pattern.

\subsection{Precipitation}

Between 17:00 UT and 22:00 UT the energy flux of ions and electrons at northern high latitudes were monitored during 9 DMSP satellite passes. Their trajectories are shown in Fig. 11, with the red lines indicating regions of enhanced electron flux, indicative of precipitation as defined for Fig. 7 (Sect. 3.4). In this instance the electron density enhancements observed on the nightside may have been on streamlines that traversed ongoing precipitation in the polar region of the morning sector.

\section{Discussion}

Two case studies have been presented showing regions of enhanced electron density in the night sector. Both occurred under quiet geomagnetic conditions when IMF $B_{z}$ was positive. In the first study IMF $B_{y}$ was negative and in the second it was strongly positive. In the first case on 5 December 2005 two clear regions of enhanced electron density were observed by the ESR $42 \mathrm{~m}$ dish on the nightside. These were colocated with the antisunward flow from polar latitudes into the auroral region observed by the SuperDARN network. Corresponding electron temperatures showed that the enhanced densities were not produced locally by precipitation. Taken collectively the observations suggest that the plasma had been produced at earlier times and had then drifted in the 


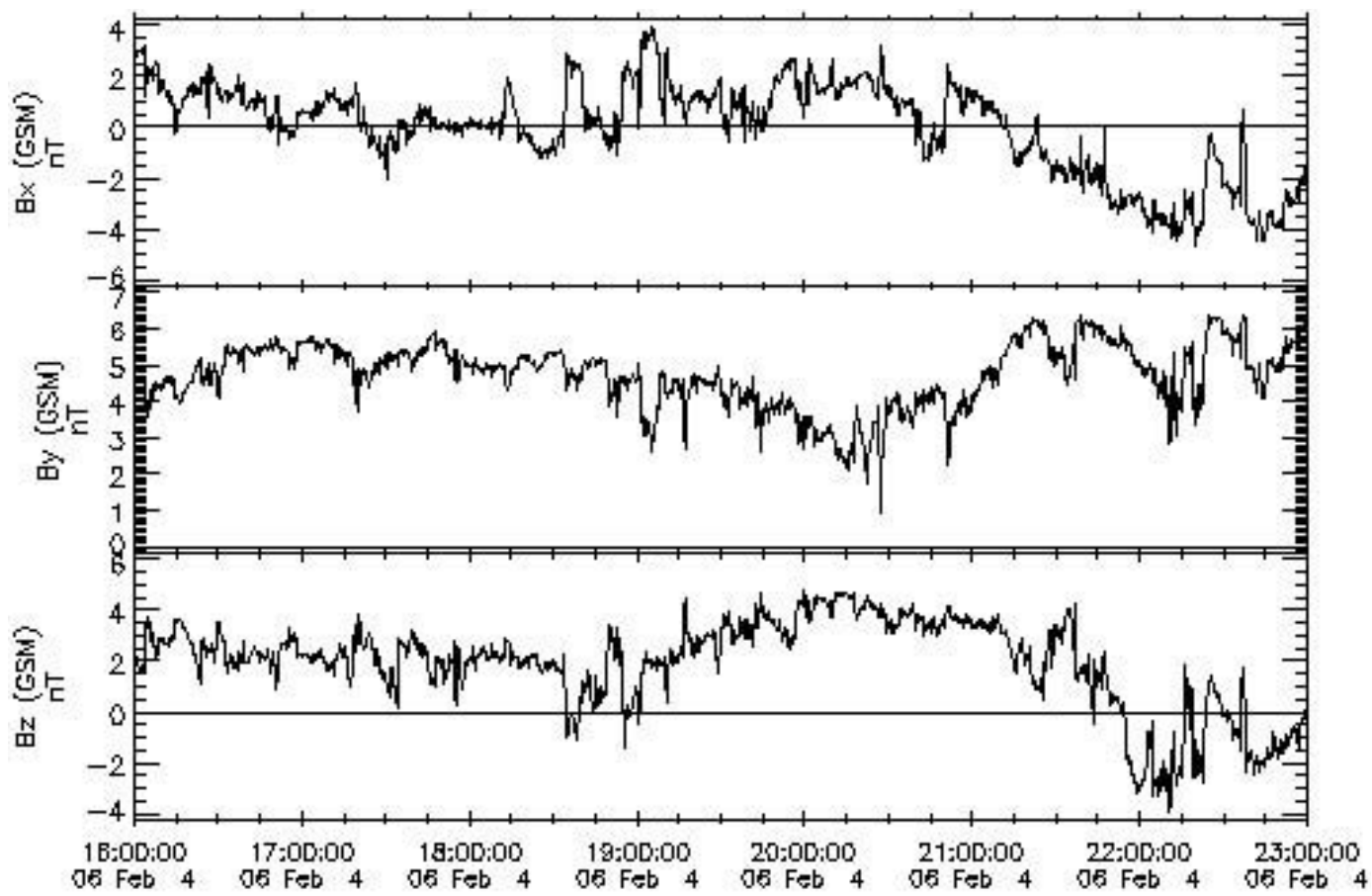

Fig. 8. The $\mathrm{x}-$, $y$ - and z-components of the interplanetary magnetic field observed by the ACE spacecraft between 16:00 UT and 23:00 UT on 4 February 2006.

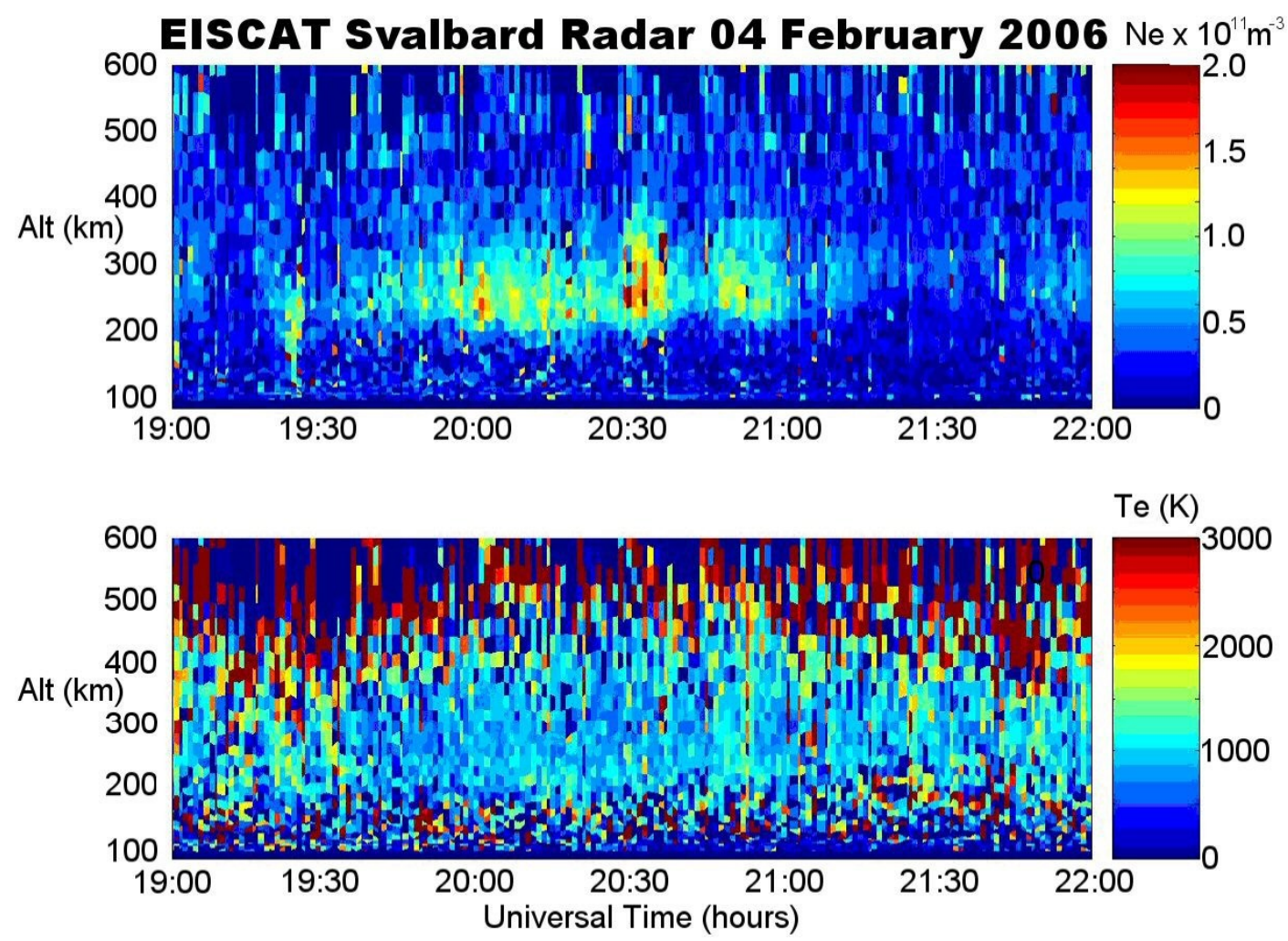

Fig. 9. Electron densities (top panel) and electron temperatures (bottom panel) measured by the $42 \mathrm{~m}$ dish of the EISCAT Svalbard Radar observing along the geomagnetic field between 19:00 UT and 22:00 UT on 4 February 2006. 

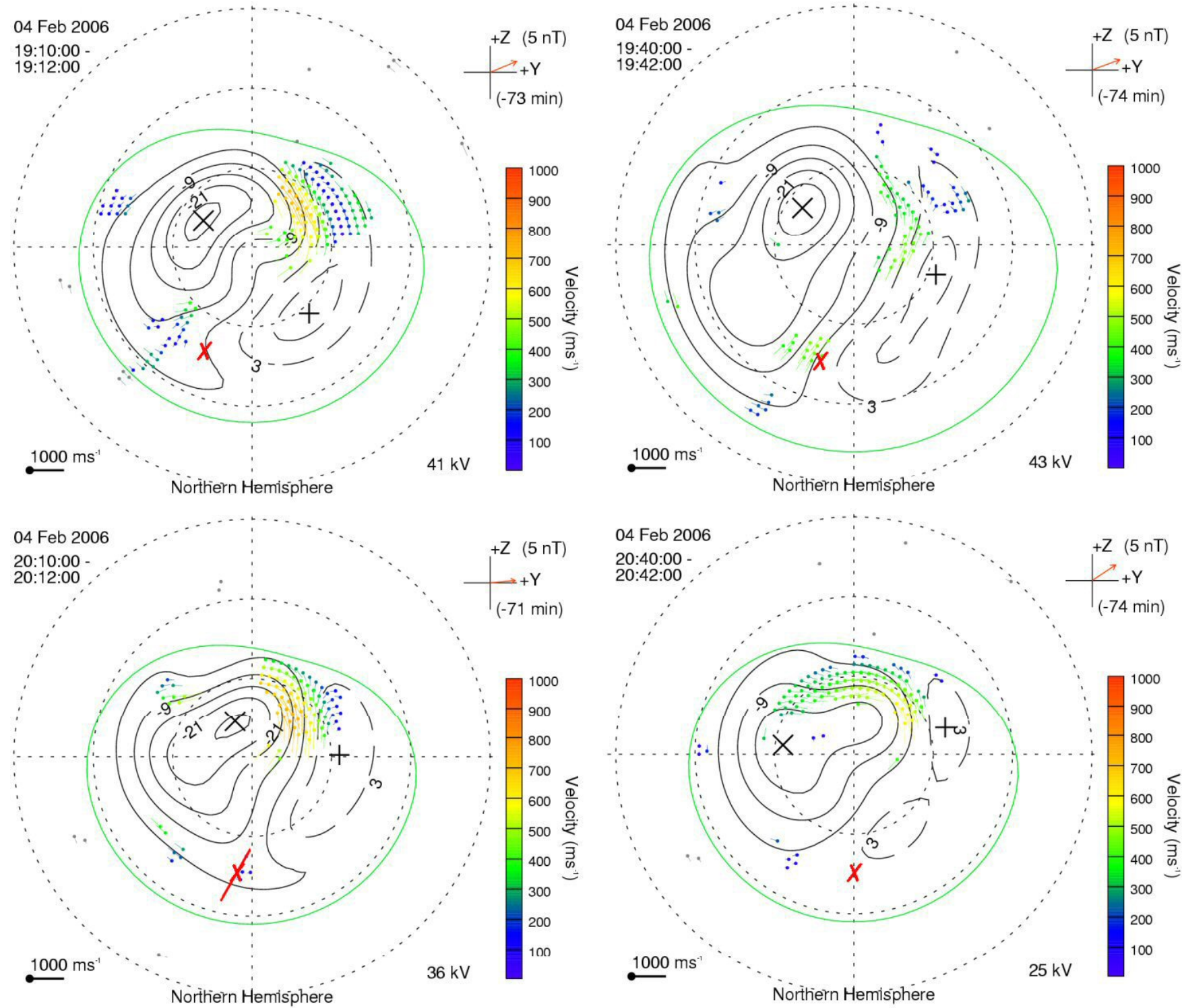

Fig. 10a. Convection patterns inferred from the SuperDARN radars for 19:10 UT, 19:40 UT, 20:10 UT and 20:40 UT on 4 February 2006. The red crosses indicate the location of the field aligned beam of the $42 \mathrm{~m}$ dish of the EISCAT Svalbard Radar at an altitude of $300 \mathrm{~km}$ and the red line indicates the positions of the $300 \mathrm{~km}$ ionospheric intersection of a scan by the $32 \mathrm{~m}$ dish of the EISCAT Svalbard Radar commencing at 19:55 UT.

antisunward convective flow to the observing location. The peak altitude of the enhancement, at $275 \mathrm{~km}$, was lower than anticipated for polar patches which are typically reported at altitudes of around $350 \mathrm{~km}$. However, patches have also been observed at lower altitudes with Weber et al. (1986) reporting patches identified by the Sondrestrom Incoherent Scatter radar at altitudes between $280 \mathrm{~km}$ and $310 \mathrm{~km}$ in the night sector. Further support for the altitude is provided by the modelling study of Zou et al. (2000) who used the Coupled Thermosphere Ionosphere Plasmasphere (CTIP) model to investigate the annual and semiannual variations in the F2 layer, and placed the altitude of nightside polar cap patches between $270 \mathrm{~km}$ and $320 \mathrm{~km}$.
Geomagnetic conditions were stable throughout the interval of interest on 5 December 2005. This was reflected by the similar general form of the SuperDARN electric potential maps; a prominent large dusk cell, a likely smaller dawn cell, and a pair of lobe cells near $85^{\circ}$ MLAT 12:00 MLT. Further support for the stability was provided by the plasma density distributions observed by the different instruments. The variation in the large scale density structure could therefore be attributed to spatial distribution, rather than local temporal variation. The large enhancement observed between 19:24 UT and 20:59 UT by the ESR $42 \mathrm{~m}$ was associated with the antisunward plasma flow of the dusk cell, while the smaller density enhancement at 21:11 UT to 21:32 UT 


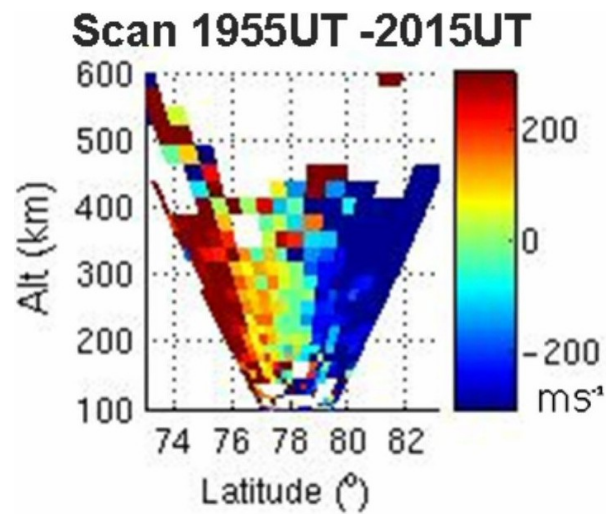

Fig. 10b. Line-of-sight plasma drift velocities measured by the $32 \mathrm{~m}$ dish of the EISCAT Svalbard Radar scanning from north to south along the geomagnetic meridian between 19:55 UT and 20:15 UT.

was likely to be associated with the antisunward flow of the dawn cell. These two enhancements were separated by a region of low, background densities that will be discussed later. Observations by the ESR $32 \mathrm{~m}$ dish, whilst scanning in latitude along the geographic meridian, showed large densities in its equatorward field-of-view that decreased gradually during the four successive scans as the radar moved to later MLTs. This enhancement was initially coincident with the main antisunward flow of the dusk cell, but weakened as the radar approached the edge of the cell near magnetic midnight. The second scan, starting at 19:47 UT, showed hints of a second, weaker enhancement at higher latitudes, separated from the main enhancement in the southern field-of-view by lower densities. The higher latitudes of the scan mapped to later MLTs than the lower latitudes, and so this secondary enhancement was interpreted as the densities convected into the nightside from the morning cell. The contrast between the densities observed in the two convection cells was also evident by comparison of the two tomography reconstructions; the earlier image at 19:11 UT showed the large densities of the dusk cell, and that for 21:15 UT displayed the low densities in the post-midnight flow.

To investigate further the possibility of photoionisation as the source of the nightside enhanced densities, simulations were performed of the flow of plasma flux tubes and of plasma decay. These simulations comprised two stages. The first estimated the time of transit of plasma between the solar terminator on the dayside and the region of observation on the nightside. This was done by tracking the location of the flux tubes at the observed nightside densities back in time, using the SuperDARN electric potential maps. Tracking was stopped when the flux tubes crossed the solar terminator, defined as where the solar zenith angle at an altitude of $300 \mathrm{~km}$ was less than $120^{\circ}$ (Roble and Rees, 1977). The procedure also estimated the MLT of where the flux tube crossed the terminator. For sample densities observed by the ESR $42 \mathrm{~m}$ radar dish at 19:45 UT, 20:15 UT and 20:45 UT on

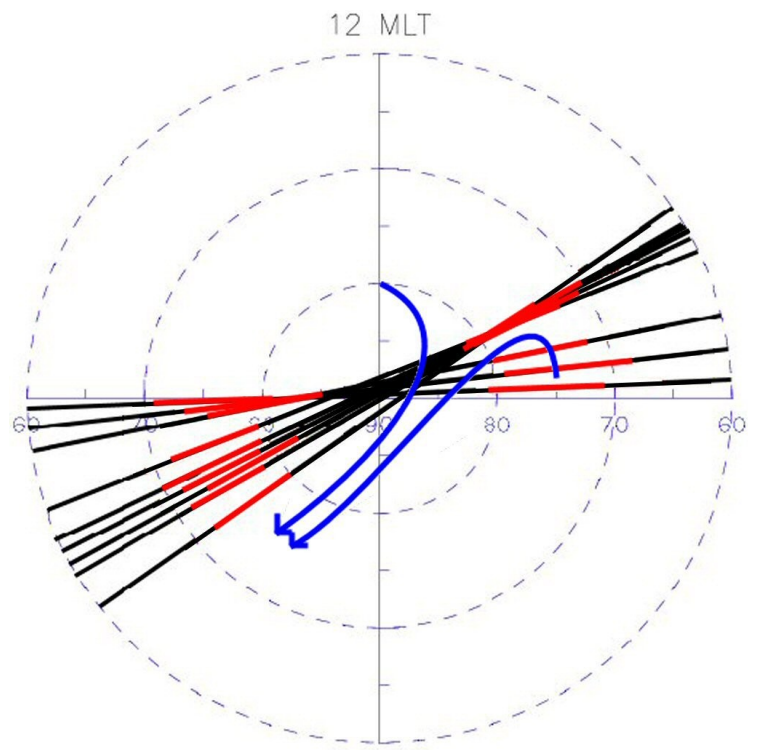

Fig. 11. The trajectories of F13, F15 and F16 DMSP satellite passes between 17:00 UT and 22:00 UT over northern high latitudes. The red portion of the trajectories indicate regions where precipitation is occurring and the blue curves show a schematic of the high latitude convection pattern.

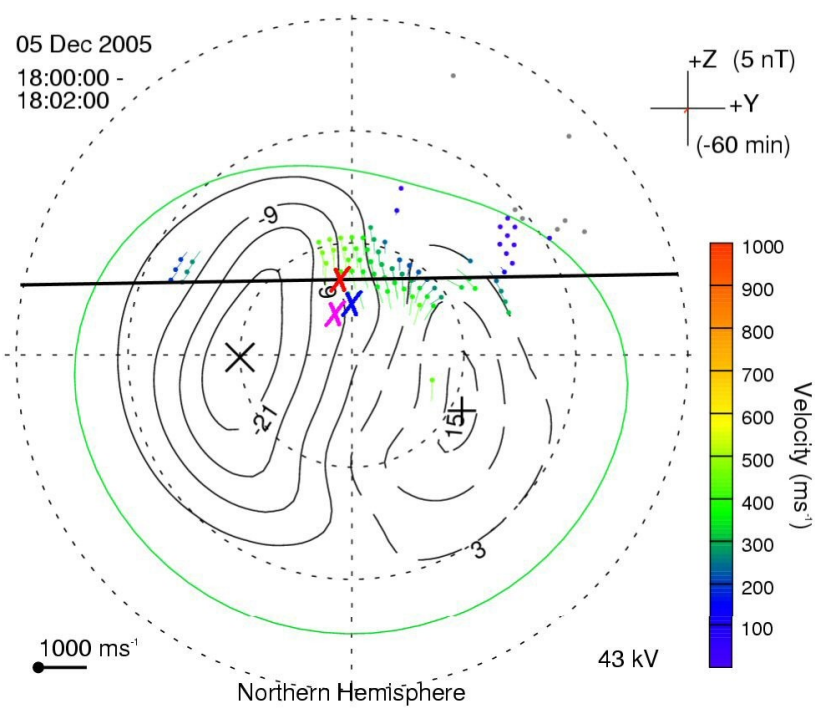

Fig. 12. Convection pattern inferred from the SuperDARN radars for 18:00 UT on 5 December 2005. The crosses indicate the locations at 18:00 UT of the electron density enhancements tracked from the nightside ionosphere from 19:45 UT (purple cross), 20:15 UT (red cross) and 20:45 UT (blue cross). The solid black line indicates the position of the terminator defined by a solar zenith angle of $120^{\circ}$ at $300 \mathrm{~km}$.

5 December 2005 the estimated transit times were $120 \mathrm{~min}$, $135 \mathrm{~min}$ and $185 \mathrm{~min}$, with the flux tubes traversing the terminator at 17:45 UT, 18:00 UT, and 17:40 UT respectively, in 
the magnetic noon and post-noon sector between 11:00 MLT and 14:00 MLT (Fig. 12). The times at which these flux tubes crossed the terminator corresponded to when the ionosphere was under the influence of weakly negative IMF $B_{z}$, however much of the transit of the ionisation occurred under conditions of IMF $B_{z}$ positive consistent with the interpretation of previous observations made over the geomagnetic pole (McEwen and Harris, 1996). Indeed it is likely that the increased transit times across the polar regions of the flux tubes observed by the ESR $42 \mathrm{~m}$ radar dish at 20:15 UT and 20:45 UT occurred due to the increasing influence of the lobe cells under IMF $B_{z}$ positive.

The second stage of the computer simulation involved using independent dayside observations of the electron density, and estimating its decay, over the transit time determined in the first stage. The decay took into consideration the number density of the neutral species $\mathrm{N}_{2}$ and $\mathrm{O}_{2}$, the ion temperature, the neutral temperature and the relative velocity between the ions and the neutrals. The number densities were estimated from MSIS-90 for $\mathrm{N}_{2}$ and $\mathrm{O}_{2}$ (Hedin, 1991). Ion temperatures on the nightside were estimated from the ESR $42 \mathrm{~m}$ radar and on the dayside were based on typical values from sunlit EISCAT observations. Plasma velocities were estimated from the SuperDARN electric potential maps. Neutral winds and neutral temperatures for the prevailing geophysical conditions were estimated using the statistical study of Killeen et al. (1995). The recombination rates of Hierl et al. (1997) were used for effective temperatures above $1300 \mathrm{~K}$ and those of St-Maurice and Torr (1978) for below $1300 \mathrm{~K}$. The Gakona Ionosonde in Alaska $\left(62.4^{\circ} \mathrm{N}, 145.1^{\circ} \mathrm{W} ; 56.5^{\circ}\right.$ MLAT, $214.5^{\circ}$ MLON) observed the dayside ionosphere when Scandinavia was in the night sector. It is a midlatitude station equatorward of the high latitude convection pattern and can therefore give a good estimate of densities caused by photoionisation without any contribution from precipitation. Gakona is at local magnetic noon at approximately 23:00 UT. Between 19:00 UT on 5 December 2005 and 00:00 UT on 6 December 2005, an interval that spanned 12:00 MLT, the peak electron density observed by the ionosonde was essentially constant at $4.5 \times 10^{11} \mathrm{~m}^{-3}$ and was located at heights in the range $200 \mathrm{~km}$ to $250 \mathrm{~km}$. This was used as input to the algorithm as the density at the terminator at an altitude of $275 \mathrm{~km}$. The lower peak altitude on the dayside is not unreasonable because the bottomside of the enhancement is eroded faster by increased recombination rates. Modelling work (Zou et al., 2000) into the annual and semiannual variations in the F2 layer placed the peak altitude on the dayside between $200 \mathrm{~km}$ and $260 \mathrm{~km}$. It should be noted that this is therefore likely to be an overestimate of the densities entrained into the high-latitude convection, with the ionosonde observations being at the peak altitude, rather than at the altitude of the nightside enhancement. Nevertheless it was the best independent measure available for the study. Over the transit time for the three flux tubes considered above, the density decayed to $(2.3 \pm 0.6) \times 10^{11} \mathrm{~m}^{-3},(2.1 \pm 0.5) \times 10^{11} \mathrm{~m}^{-3}$ and $(1.6 \pm 0.4) \times 10^{11} \mathrm{~m}^{-3}$, respectively, the error being set primarily by uncertainties in the recombination coefficients and neutral densities. For quantitative comparison with the observations, a 30-min window has been considered centred on each of the time epochs of interest. Within each window the five largest density values at the peak altitude of $275 \mathrm{~km}$ were determined, and averaged to obtain a mean value for the interval. The purpose of this was to reduce the effect of rapid variation due to small-scale structure on the comparisons. Mean values of $2.1 \times 10^{11} \mathrm{~m}^{-3}, 1.8 \times 10^{11} \mathrm{~m}^{-3}$ and $1.6 \times 10^{11} \mathrm{~m}^{-3}$ were obtained for the windows centred on 19:45 UT, 20:15 UT and 20:45 UT, in reasonable agreement with the predicted values. The slight overestimations are a likely consequence of the overestimation of the initial electron density.

The electron density enhancement observed in the postmidnight sector between 21:11 UT and 21:32 UT had lower density values, with an average of $0.8 \times 10^{11} \mathrm{~m}^{-3}$, compared with that in the pre-midnight sector, with an average of $1.4 \times 10^{11} \mathrm{~m}^{-3}$. When flux tubes from the post-midnight sector were traced backwards through the convection pattern to the solar terminator they had a transit time of $90 \mathrm{~min}$ and originated in the morning sector around 08:00 MLT. This sector is close to sunrise and plasma densities rapidly increased at dawn, with the Gakona ionosonde observing densities increasing by a factor of 10 between 07:00 MLT and 09:00 MLT. Meaningful comparisons between calculated and observed densities could not therefore be drawn.

The flux tubes containing the low electron densities observed by the ESR between the two enhancements (20:59 UT and 21:11 UT) were tracked back in time to a region antisunward of the pair of lobe cells with a transit time of $100 \mathrm{~min}$ to this point. Lack of data in the SuperDARN electric potential maps meant that no meaningful information could be deduced regarding their earlier history. In this region plasma flow was very slow $\left(\sim 50 \mathrm{~m} \mathrm{~s}^{-1}\right)$ and so if any enhancement from dayside photoionisation had been present it would have decayed to background values during the extremely long transit time. This effectively resulted in the lobe cells preventing the flow of enhanced dayside plasma into the magnetic midnight sector.

Geophysical conditions were very similar in the second case study on 4 February 2006 to those of the former study, except IMF $B_{y}$ was strongly positive rather than weakly negative. Previous studies (King and Smith, 1968; Zou et al., 2000) have shown the months of November to February to be in a winter regime of larger electron densities at $65^{\circ} \mathrm{N}$ at local noon than in other seasons and therefore observations on 5 December 2005 and 4 February 2006 can be directly compared. Enhanced electron densities were also observed on 4 February 2006 by the ESR $42 \mathrm{~m}$ dish with a peak altitude of $255 \mathrm{~km}$. As in the previous study these were in antisunward flow and corresponded to electron temperatures that showed they were not due to local precipitation. 
When a flux tube at 20:30 UT, within the electron density enhancement observed by the ESR between 19:55 UT and 20:36 UT, was traced backwards through the convection pattern it was predicted to cross the terminator 100 min earlier in the dawn magnetic sector at 08:00 MLT under conditions of IMF $B_{z}$ positive. It is likely that the flux tubes were drawn from the dusk cell which, due to the large positive values of IMF $B_{y}$, extended into the dawn sector. However uncertainties in the trajectory tracking meant that a location in the dawn cell could not be ruled out. The Gakona ionosonde observed peak dayside electron densities when it was in sunlight spanning magnetic noon between 20:00 UT on 4 February 2006 and 01:00 UT on 5 February 2006 which were essentially constant at $4.0 \times 10^{11} \mathrm{~m}^{-3}$ at altitudes of between $200 \mathrm{~km}$ and $250 \mathrm{~km}$. The peak electron densities on the nightside were at $255 \mathrm{~km}$, a lower altitude than on 5 December 2005 and so recombination rates were faster. The calculation of plasma decay was therefore carried out at an altitude of $255 \mathrm{~km}$ and the predicted nightside electron density in this instance was $(1.1 \pm 0.3) \times 10^{11} \mathrm{~m}^{-3}$ in good agreement with the observed value of $1.3 \times 10^{11} \mathrm{~m}^{-3}$. While no in situ precipitation was observed in the magnetic midnight sector, the DMSP spacecraft observed precipitation in the dawn sector from where this plasma was drawn and this may have led to the slightly larger observed electron densities than those predicted.

\section{Conclusions}

Two case studies have been presented of long-lived electron density enhancements in the nightside winter ionosphere under conditions of IMF $B_{z}$ positive. In the first of these studies on 5 December 2005, the enhancement observed before magnetic midnight was attributed to photoionisation from near magnetic noon on the dayside that had drifted to the nightside in the convective flow. The calculation of decay rates supported this interpretation. A second region of enhanced electron density observed after magnetic midnight was associated with flux tubes originating in the dawn sector. A region of lower electron density separating these two enhancements was attributed to a pair of lobe cells effectively blocking antisunward plasma flow from the dayside. A second study under similar geophysical conditions on 4 February 2006 but with IMF $B_{y}$ positive, observed plasma in the nightside ionosphere of dayside origin, drawn from the magnetic morning sector. The observations show that, under conditions of IMF $B_{z}$ positive, plasma originating on the dayside can play a significant role in the nightside ionosphere.

Acknowledgements. Financial support for the project was provided by the UK Science and Technology Facilities Council under grants PP/E001157/1. The assistance of the University of Troms $\emptyset$ and the Norwegian Polar Institute in the tomographic measurements is gratefully acknowledged. EISCAT is an international facility supported by the national science councils of China, Finland, France,
Germany, Japan, Norway, Sweden and UK. The SuperDARN radar facility is funded by the National Research Programs of Australia, Canada, Finland, Japan, South Africa, Sweden, UK and USA and the electric potential map data was provided by Tim Yeoman and Adrian Grocott at the University of Leicester. The IMF data was provided by $\mathrm{N}$. Ness and obtained from the CDAWeb. The DMSP particle detectors data was obtained from the JHU/APL website. A. G. Wood acknowledges receipt of a STFC postgraduate studentship.

Topical Editor K. Kauristie thanks H. Carlson and another anonymous referee for their help in evaluating this paper.

\section{References}

Bowline, M. D., Sojka, J. J., and Schunk, R. W.: Relationship of theoretical patch climatology to polar cap patch observations, Radio Sci., 31, 635-644, 1996.

Brekke, A.: Physics of the Upper Polar Atmosphere, Wiley-Praxis Series in Atmospheric Physics, 1997.

Buchau, J., Reinisch, B. W., Weber, E. J., and Moore, J. G.: Structure and dynamics of the winter polar cap F region, Radio Sci., 18, 995-1010, 1983.

Buchau, J., Weber, E. J., Anderson, D. N., Carlson Jr., H. C., Moore, J. G., Reinisch, B. W., and Livingston, R. C.: Ionospheric structures in the polar cap: Their origin and relation to $250-\mathrm{MHz}$ scintillation, Radio Sci., 20, 325-338, 1985.

Coley, W. R. and Heelis, R. A.: Seasonal and universal time distribution of patches in the northern and southern polar caps, J. Geophys. Res., 103, 29 229-29 237, 1998.

Crowley, G.: Critical Review of patches and blobs, in Polar Cap Boundary Phenomena, in: URSI Review of Radio Science 19931996, edited by: Stone, W. R., published for the International Union of Radio Science by the Oxford University Press, 619648, 1996.

Freeman, M. P., Farrugia, C. J., Burlaga, L. F., Hairston, M. R., Greenspan, M. E., Ruohoniemi, J. M., and Lepping, R. P.: The interaction of a magnetic cloud with the Earth: Ionospheric convection in the Northern and Southern Hemispheres for a wide range of quasi-steady interplanetary magnetic field conditions, J. Geophys. Res., 98, 7633-7655, 1993.

Greenwald, R. A., Baker, K. B., Dudeney, J. R., Pinnock, M., Jones, T. B., Thomas, E. C., Villain, J.-P., Cerisier, J.-C., Senior, C., Hanuise, C., Hunsucker, R. D., Sofko, G., Koehler, J., Nielsen, E., Pellinen, R., Walker, A. D. M., Sato, N., and Yamagishi, H.: SuperDARN: A global view of the dynamics of high-latitude convection, Space Sci. Rev., 71, 761-796, 1995.

Hardy, D. A., Schmitt, L. K., Gussenhoven, M. S., Marshell, F. J., Yeh, H. C., Schumaker, T. L., Huber, A., and Pantazis, J., Precipitating electron and ion detectors (SSJ/4) for the block 5D/flights 6-10 DMSP satellites: Calibration and data presentation, Rep. AFGL-TR-84-0317, Air Force Geophys. Lab., Hanscom AFB, Mass., 1984.

Hedin, A. E.: Extension of the MSIS Thermospheric Model into the Middle and Lower Atmosphere, J. Geophys. Res., 96, 1159 1172, 1991.

Heelis, R. A.: Studies of ionospheric plasma and electrodynamics and their application to ionosphere-magnetosphere coupling, Rev. Geophys., 26, 317-328, 1988. 
Hierl, P. M., Dotan, I., Seeley, J. V., Van Doren, J. M., Morris, R. A., and Viggiano, A. A.: Rate constants for the reactions of $\mathrm{O}^{+}$ with $\mathrm{N}_{2}$ and $\mathrm{O}_{2}$ as a function of temperature (300-1800 K), J. Chem. Phys., 106, 3540-3544, 1997.

Killeen, T. L., Won, Y.-I., Niciejewski, R. J., and Burns, A. G.: Upper thermosphere winds and temperatures in the geomagnetic polar cap: Solar cycle, geomagnetic activity, and interplanetary magnetic field dependencies, J. Geophys. Res., 100, $21327-$ $21342,1995$.

King, J. W. and Smith, P. A.: The seasonal anomaly in the behaviour of the F2-layer critical frequency, J. Atmos. Terr. Phys., 30, 1707-1713, 1968.

Lockwood, M. and Moen, J.: Reconfiguration and closure of lobe flux by reconnection during northward IMF: possible evidence for signatures in cusp/cleft emissions, Ann. Geophys., 17, 9961011, 1999,

http://www.ann-geophys.net/17/996/1999/.

Lockwood, M., Sandholt, P. E., Cowley, S. W. H., and Oguti, T.: Interplanetary magnetic field control of dayside auroral activity and the transfer of momentum across the dayside magnetopause, Planet. Space Sci., 37, 1347-1365, 1989.

Lorentzen, D. A., Shumilov, N., and Moen, J.: Drifting airglow patches in relation to tail reconnection, Geophys. Res. Lett., 31, L02806, doi:10.1029/2003GL017785, 2004.

McEwen, D. J. and Harris, D. P.: Occurrence patterns of $F$ layer patches over the north magnetic pole, Radio Sci., 31, 619-628, 1996.

Middleton H. R., Pryse, S. E., Kersley, L., Bust, G. S., Fremouw, E. J., Secan, J. A., and Denig, W. F.: Evidence for the tongue of ionisation under northward interplanetary magnetic field conditions, J. Geophys. Res., 103, A07301, doi:10.1029/2004JA010800, 2005.

Moen, J., Gulbrandsen, N., Lorentzen, D. A., and Carlson, H. C.: On the MLT distribution of $F$ region polar cap patches at night, Geophys. Res. Lett., 34, L14113, doi:10.1029/2007GL029632, 2007.

Pedersen, T. R., Fejer, B. G., Doe, R. A., and Weber, E. J.: An incoherent scatter radar technique for determining two-dimensional horizontal ionization structure in polar cap $\mathrm{F}$ region patches, J. Geophys. Res., 105, 10 637-10 655, 2000.

Pryse, S. E.: Radio tomography - a new experimental technique, Surv. Geophys., 24, 1-38, 2003.

Pryse, S. E., Wood, A. G., Middleton, H. R., McCrea, I. W., and Lester, M.: Reconfiguration of polar-cap plasma in the magnetic midnight sector, Ann. Geophys., 24, 2201-2208, 2006, http://www.ann-geophys.net/24/2201/2006/.

Reiff, P. H. and Burch, J. L.: IMF $B_{y}$-Dependent Plasma Flow and Birkeland Currents in the Dayside Magnetosphere 2. A Global Model for Northward and Southward IMF, J. Geophys. Res., 90, 1595-1609, 1985.
Roble, R. G. and Rees, M. H.: Time-dependent studies of the aurora: Effects of particle precipitation on the dynamic morphology of ionospheric and atmospheric properties, Planet. Space Sci., 25, 991-1010, 1977.

Ruohoniemi, J. M. and Baker, K. B.: Large-scale imaging of highlatitude convection with Super Dual Auroral Radar Network HF radar observations, J. Geophys. Res., 103, 20 797-20 811, 1998.

Ruohoniemi, J. M. and Greenwald, R. A.: Dependencies of high-latitude plasma convection: Consideration of interplanetary magnetic field, seasonal, and universal time factors in statistical patterns, J. Geophys. Res., 110, A09204, doi:10.1029/2004JA010815, 2005.

Sojka, J. J., Bowline, M. D., and Schunk, R. W.: Patches in the polar ionosphere: UT and seasonal dependence, J. Geophys. Res., 99, 14 959-14 970, 1994.

St-Maurice, J.-P. and Torr, D. G.: Nonthermal rate coefficients in the ionosphere: The reactions of $\mathrm{O}^{+}$with $\mathrm{N}_{2}, \mathrm{O}_{2}$ and NO, J. Geophys. Res., 83, 969-977, 1978.

Tsunoda, R. T.: High-latitude F region irregularities: A review and synthesis, Rev. Geophys., 26, 719-760, 1988.

Valladares, C. E., Fukui, K., Sheehan, R., Carlson, H. C., and Bullet, T.: Simultaneous observations of polar cap patches and sunaligned arcs during transition of the IMF, Radio Sci., 33, 1829$1845,1988$.

Walker, I. K., Moen, J., Kersley, L., and Lorentzen, D. A.: On the possible role of cusp/cleft precipitation in the formation of polarcap patches, Ann. Geophys., 17, 1298-1305, 1999, http://www.ann-geophys.net/17/1298/1999/.

Weber, E. J., Buchau, J., Moore, J. G., Sharber, J. R., Livingston, R. C., Winningham, J. D., and Reinisch, B. W.: F layer ionisation patches in the polar cap, J. Geophys. Res., 89, 1683-1694, 1984.

Weber, E. J., Klobuchar, J. A., Buchau, J., Carlson Jr, H. C., Livingston, R. C., de la Beaujadiere, O., McCready, M., Moore, J. G., and Bishop, G. J.: Polar cap $F$ layer patches: Structure and dynamics, J. Geophys. Res., 91, 12 121-12 129, 1986.

Zou, L., Rishbeth, H., Müller-Wodarg, I. C. F., Aylward, A. D., Millward, G. H., Fuller-Rowell, T. J., Idenden, D. W., and Moffett, R. J.: Annual and semiannual variations in the ionospheric F2-layer. I. Modelling, Ann. Geophys., 18, 927-944, 2000, http://www.ann-geophys.net/18/927/2000/.

Zwickl, R. D., Doggett, K., Sahm, S., Barrett, W. P., Grubb, R. N., Detman, T. R., Raben, V. J., Smith, C. W., Riley, P., Gold, R. E., Mewaldt, R. A., and Maruyama, T.: The NOAA Real-Time Solar-Wind (RTSW) System Using ACE Data, Space Sci. Rev., 86, 633-648, 1998. 